\title{
Length-weight relationship and condition factor of Micropogonias furnieri (Desmarest) (Perciformes, Sciaenidae) in the Sepetiba Bay, Rio de Janeiro State, Brazil
}

\author{
Marcus Rodrigues da Costa \& Francisco Gerson Araújo
}

Laboratório de Ecologia de Peixes, Universidade Federal Rural do Rio de Janeiro. Antiga Rodovia Rio-São Paulo Km 47, 23851-970 Seropédica, Rio de Janeiro,Brasil.E-mail: gerson@ufri.br; profmar@ig.com.br

\begin{abstract}
The length-weight relationship and spatial, temporal and ontogenetic changes in the condition factor of Micropogonias furnieri (Desmarest, 1823) were analyzed, from samples collected between October 1998 and September 1999, in the Sepetiba Bay, a coastal area with a wide communication with the sea $\left(22^{\circ} 54^{\prime}-23^{\circ} 04^{\prime} \mathrm{S}\right.$, $43^{\circ} 34^{\prime}-44^{\circ} 10^{\prime} \mathrm{W}$ ) at Southeast Brazil. The aim was to supply basic information on the form of growth of the population of M. furnieri that uses the bay, as well as to assess changes in the fish condition. Most fish were young and subadults. The length-weight equation, based on 2499 unsexed individuals, was $W_{t}=0.009095 * L_{t}^{2.99}$, where $\mathrm{W}_{t}$ is the total weight $(\mathrm{g})$ and $\mathrm{L}_{t}$ is the total length $(\mathrm{cm})$. The regression constant and the regression coefficient presented significant inverse relationship $(\mathrm{p}<0.01)$, indicating that the regression coefficient from the lengthweight relationship is not a good parameter for characterizing different populations, because its strong association between one another. The best condition was recorded in October/November and April, and the worst, between January and March. Spatially, the best condition was observed in the inner bay zone, where most fish were young-of-the-year, and in the outer zone where predominate larger sized fish, indicating that individuals of intermediary size could be allocating large amount of energy for growth, presenting, consequently, lowest condition. Isometry was detected for M. furnieri populations at Sepetiba Bay, and variations in physiologic condition could be associated to feeding availability, mainly in the inner zone, where the harsh water quality would not be constrained for development of this species.
\end{abstract}

KEY WORDS. Coastal fish, fish occurence, ichthyofauna, tropics, white croaker.

Micropogonias furnieri (Desmarest, 1823) is a member of Sciaenidae with a wide geographical distribution in Western Atlantic (Caribbean to Argentina), which occur in sandy and muddy bottoms, showing demersal habits VAzzoler (1991). It ranks among the most abundant fish in Sepetiba Bay, contributing to $8.5 \%$ of the total number and occurring in $20 \%$ of beach seine samples; in otter trawling it contribute to $5.8 \%$ of the total number, being present in $68 \%$ of the samples Araújo et al. (1997, 1998).

The length-weight relationship $\left(\mathrm{W}_{\mathrm{t}} / \mathrm{L}_{\mathrm{t}}\right)$ has been widely used in fish biology with several purposes (e.g. to estimate the mean fish weight of the fish, based on the known length BEYER (1987); conversion of the length equations in weight for equivalent of growth in weight; morphometrics interespecific and intrapopulational comparisons; and to assess the index of well-being of the fish populations BOLGER \& Connolly (1989). The length-weight equation is also a quantitative expression of the development at corporal level of an organism. An ample range of variation in the alometric coefficient is expected for such a widely distributed populations, as results of different habitats along the Brazilian coast, with higher values been expected for estuaries and rich semi-closed environments and lower values for coastal open areas and offshore zones VAzzoler (1991).

The condition factor (K) (LE CREN 1951) is a quantitative parameter of the Well-being State of the fish and reflects recent feeding conditions. This factor varies according to influences of physiologic factors, fluctuating according to different stages of the development. ANDERSON \& NEUMANN (1996) refer to length/ weight data of population, as basic parameters for any monitoring study of fisheries, since it provides an important information concerning the structure and function of populations.

The objective here is to determine the length-weight relationship and the variations in the condition factor among months, zones and sizes of $M$. furnieri populations in the Sepetiba Bay. 


\section{MATERIAL AND METHODS}

\section{Study area}

Sepetiba Bay is located at South coast of Rio of January State $\left(22^{\circ} 54^{\prime}-23^{\circ} 04^{\prime} \mathrm{S}, 43^{\circ} 34^{\prime}-44^{\circ} 10^{\prime} \mathrm{W}\right)$ presenting $520 \mathrm{Km}^{2}$ area and approximately $2500 \mathrm{Km}^{2}$ watershed. Its rectangular form is limited at North and East by the continent, at South by the thin Marambaia sandbank and at West by the Ocean and Ilha Grande Bay (Fig. 1). Its perimeter is approximately $123 \mathrm{~km}$, with maximum length of $43 \mathrm{~km}$ (East-West) and width of 17 $\mathrm{km}$ (North-South). Maximum depth is $30 \mathrm{~m}$, but about $40 \%$ of its area present depth $<5 \mathrm{~m}$, mainly in the inner zone.

The Bay area was divide in tree zones according two a environmental gradient of salinity and depth. The outer zone has a sand and gravel bottom and is close to the sea limit; the inner zone has a heavy mud bottom and is located within a protected area of the bay; and the central zone has a mud bottom.

The Bay receives influences of the northward denser and colder oceanic waters of Falkland currents, that penetrate in the bay at westside, receiving warmer freshwater from continental drainage, becoming superficial as it surround the inner Bay (Coelho \& CaRvalHo 1973). Several rivers and drainage channels carry into the Bay, bringing alluviums and efluents from several organic pollutants. The largest freshwater contribution comes from São Francisco channel (River Guandu), that brings waters originally abstracted from Paraíba do Sul river through power generation hydreletric LIGHT-CEDAE system, which is also used to Rio de Janeiro Municipality water supply.

Substrate is mainly muddy, due to protection of the sandbank and several Bay islands, predominating silt and clay bottoms, with few areas of sand and gravel areas, in the outer Bay, near to the sea connection.

\section{Sampling}

A total of 2499 individuals of $M$. furnieri were examined, in two monthly sampling programmes, one beach seine and other otter trawl, carried out from October 1998 to September 1999. Five sampling sites for beach seine were established, distributed in two Bay zones: outer Bay (sites: 1, 2 and 3) and inner Bay (sites: 4 and 5) (Fig. 1). Beach seines were accomplished by towing the net ( $10 \mathrm{~m}$ long, $2.5 \mathrm{~m}$ height and $7 \mathrm{~mm}$ mesh size) parallel to the coastline at a depth up to $1.5 \mathrm{~m}$, in an extension of approximately $30 \mathrm{~m}$, with 3 replicates (pseudoreplicates). Standardized unit sample was the number of total fish caught per seine.

Otter trawling were performed using a $12 \mathrm{~m}$ long boat, provided by a $12 \mathrm{~mm}$ mesh at the cod end, $25 \mathrm{~mm}$ at lateral, with $8 \mathrm{~m}$ opening mouth. Standardized tows were $20 \mathrm{~min}$ long, covering an extension of approximately $1.5 \mathrm{~km}$, with three replicates. Unit sampling were the total number of fish captured in a tow. All fishes collected were placed in plastic bags, fixed in $10 \%$ formalin, and identified according to Menezes \& Figueiredo (1980), measured at total length, counted and weighed at $0.1 \mathrm{~g}$. Eventual influence of stomachs fullness index and maturations stage, were not considered for condition factor calculation.

Condition factor and length-weight relationship were assessed from measurement of total weight (Wt) and total length (Lt), and the curves parameters $\mathbf{a}$ and $\mathbf{b}$ were determined

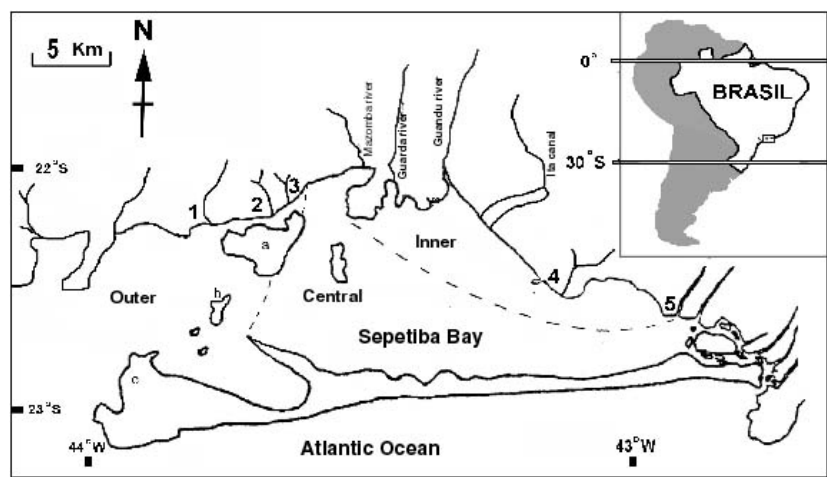

Figura 1. Study area, Sepetiba Bay, with indication of the zones and sampling sites. Beach seine: Outer zone - (1) Muriqui, (2) Itacuruça, (3) Coroa Grande; Inner zone - (4) Sepetiba, (5) Pedra de Guaratiba; Otter trawl - Outer, Central and Inner zones; (a) Itacuruça Isle; (b) Jaguanum Isle; (c) Marambaia Isle.

by log 10 transformation of raw data, following VAzzoler et al. (1981) and BRAGA (1986). Growth curves obtained from straight line for regression between total weight and total length is: $\log \mathrm{Wt}=\log \mathrm{a}+\mathrm{b}{ }^{*} \log \mathrm{Lt}$, where Wt is the total weight (g) (dependent variable), Lt is the total length $(\mathrm{cm})$ (independent variable), $\mathbf{a}$ is the regression constant and $\mathbf{b}$ is the regression coefficient. The theoretical equation of the length-weight relationship followed the equation $\mathrm{Wt}=\mathrm{a}{ }^{*} \mathrm{Lt}^{\mathrm{b}}$.

Condition factor - K (LE CREN 1951) was assessed for comparisons among months, sites and sizes, was determined according to Vazzoler et al. (1981) and Vazzoler (1996), by the following expression: $\mathrm{k}=\mathrm{Wt} / \mathrm{Lt}^{\mathrm{b}}$, where $\mathrm{k}$ corresponds to the condition factor and $\mathbf{b}$ is the alometry coefficient related with the form of the individuals growth, calculated from the lengthweight relationship. The degree of adjustment of the model studied was assessed by the correlation coefficient of Pearson (r) for the logaritmized data of the length-weight relationship. For seasons comparisons, the sampling months were grouped as follows: Spring (October, November and December), Summer (January, February and March), Autumn (April, May and June) and Winter (July, August and September).

\section{RESULTS}

The length-weight relationship was determined by the following equation: $\mathrm{Wt}=0.009095{ }^{*} \mathrm{Lt}^{2.99}$ (Fig. 2). This equation corresponds to the logaritimized form, $\ln \mathrm{W}=-4.7+2.99$

* $\ln \mathrm{L}(\mathrm{r}=0.99)$. The values related to the well-being index present the highest values associated to the individuals that present highest weights for a given length. The highest $\mathbf{b}$ values indicate the inflection of the curve for the assintotic values, indicating alometric growth, that is, the length becomes a irrelevant variable in relation to the weight.

The linear correlation coefficients was closed to 1 , suggesting a good adjustment of the data. The alometric coefficient (b) presented higher values from January to March, and lower values in October/December and April.

The regression constant presented an inverse relationship with the regression coefficient (Tab. I). This relationship 
Table I. Results of the regression analysis and t- Student test for the length/weight data and regression coefficient of Micropogonias furnieri, from October 1998 to September 1999. (n) Number of individuals, (A) regression constant; (k) condition factor, (a and b) parameters of length/weight equation.

\begin{tabular}{lrccccccc}
\hline \multicolumn{1}{c}{ Meses } & $\mathrm{n}$ & $\mathrm{r}$ & $\mathrm{A}$ & $\mathrm{a}$ & $\mathrm{k}$ & $\mathrm{b}$ \\
\hline October & 119 & 0.99 & -4.42 & 0.0120 & $0.0121 \pm 0.0001$ & 2.89 & $-8.43^{*}$ \\
November & 114 & 0.99 & -4.65 & 0.0095 & $0.0104 \pm 0.0001$ & 2.98 & -1.48 \\
December & 476 & 0.99 & -4.63 & 0.0097 & $0.0098 \pm 0.0001$ & 2.91 & $-13.93^{*}$ \\
January & 78 & 0.99 & -5.40 & 0.0045 & $0.0043 \pm 0$ & 3.30 & $18.63^{*}$ \\
February & 5 & 0.99 & -6.02 & 0.0024 & $0.0020 \pm 0.0001$ & 3.55 & $6.78^{*}$ \\
March & 53 & 0.98 & -5.24 & 0.0053 & $0.0051 \pm 0.0001$ & 3.23 & $8.21^{*}$ \\
April & 79 & 0.96 & -4.67 & 0.0093 & $0.0105 \pm 0.0001$ & 2.98 & -0.61 \\
May & 183 & 0.99 & -4.79 & 0.0083 & $0.0094 \pm 0.0001$ & 3.03 & $2.83^{*}$ \\
June & 142 & 0.99 & -4.94 & 0.0071 & $0.0073 \pm 0.0001$ & 3.15 & $12.65^{*}$ \\
July & 531 & 0.99 & -4.83 & 0.0079 & $0.0066 \pm 0.0001$ & 3.16 & $26.22^{*}$ \\
August & 325 & 0.99 & -4.80 & 0.0082 & $0.0083 \pm 0$ & 3.05 & $6.28^{*}$ \\
September & 394 & 0.98 & -5.11 & 0.0060 & $0.0060 \pm 0$ & 3.13 & $12.86^{*}$ \\
\hline
\end{tabular}

*Signifcantly different from three at $99 \%$ level of confidence.

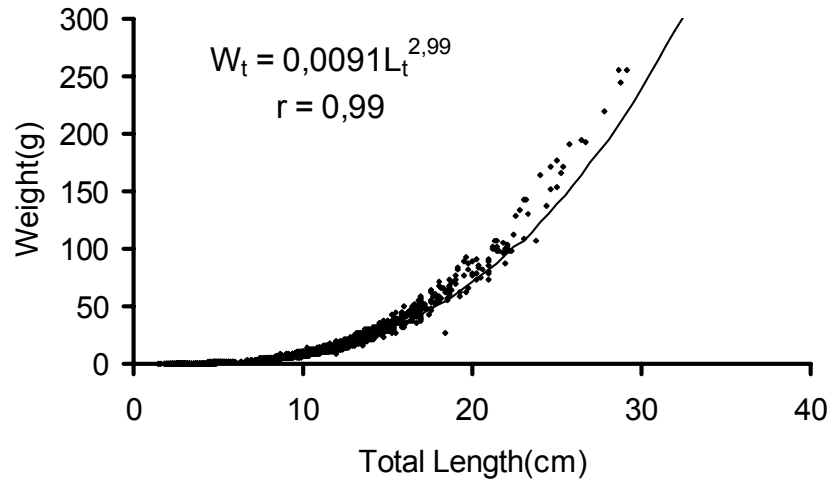

Figura 2. Length-weight relationship for Micropogonias furnieri in the Sepetiba Bay, Rio de Janeiro.

is confirmed when the regression coefficient is compared to monthly transformed constant of regression values of the length-weight relationship curve. The exponential negative curve obtained is represented by the following equation: $\mathrm{y}=$ $8.4769 \mathrm{e}^{-2.281 \mathrm{x}},(\mathrm{r}=-0.96)$, and a tendency for higher $\mathrm{b}$ larger occur with lower a values (Fig. 3).

The factor of condition, obtained monthly, presented higher values in October/November and April and lower values between January and March (Fig. 4).

Seasonally, condition factor means were higher in spring, coinciding with highest numbers of youngs-of-the-year, recorded by beach seines. The worst condition was observed in Summer, when no such young fish were recorded in the samples.

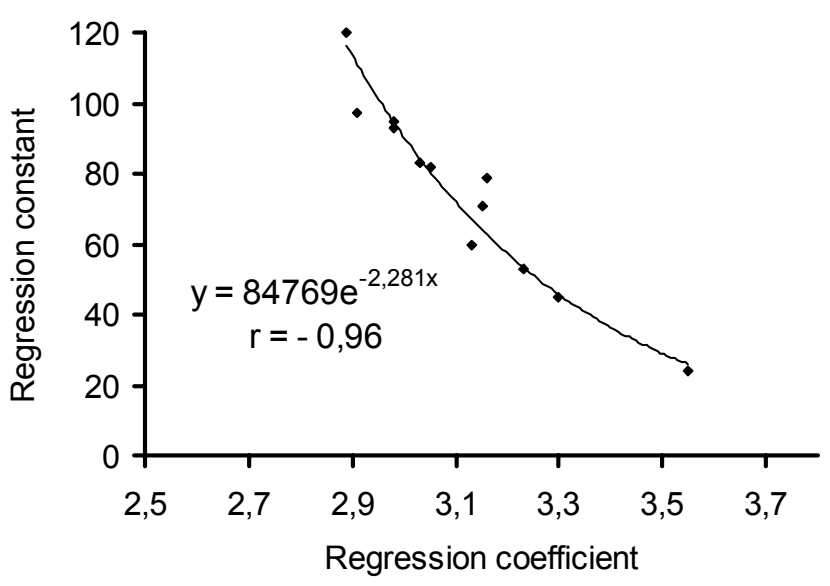

Figura 3. Diagram of monthly values of the regression coefficient (b) against the regression constant (a) $\left(\times 10^{-4}\right)$, from length-weight relationship.

Spatially, the best fish condition was recorded in the inner Bay zone, where most recruits, basically youngs-of-the-year occur. The second best condition was recorded in the outer zone, where adults predominated. The lowest condition was recorded in the central zone, where individuals of different size class occurred (Fig. 5).

The mean condition factor in relation to size class is presented in figure 6 . The higher mean values tend to be higher in extreme class of sizes, that is, youngs-of-the-year (LT $<50$ $\mathrm{mm})$, or adults $(\mathrm{LT}=250-300 \mathrm{~mm})$. In intermediate sizes $(\mathrm{LT}=$ $50-200 \mathrm{~mm})$, the worst conditions were found. 

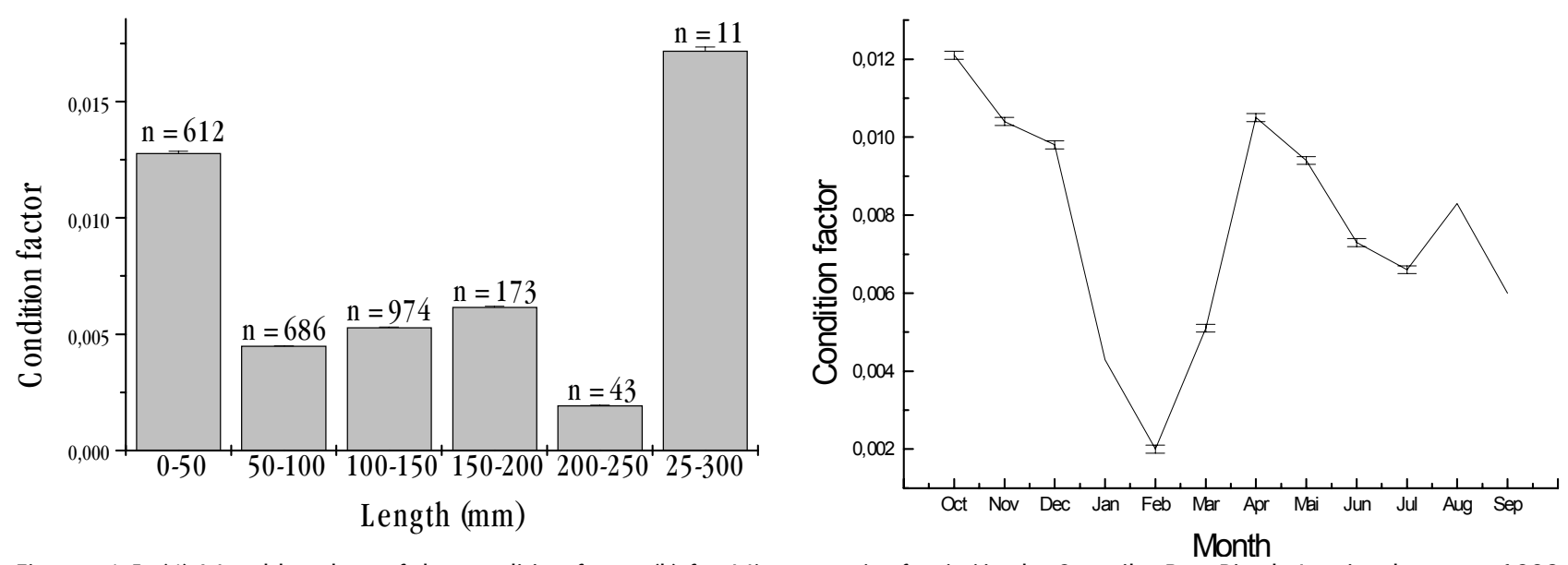

Figures 4-5. (4) Monthly values of the condition factor (k) for Micropogonias furnieri in the Sepetiba Bay, Rio de Janeiro, between 1998 and 1999; (5) Means + standard error of condition factor for Micropogonias furnieri in Sepetiba Bay, Rio de Janeiro, per zones. $\mathrm{n}=$ number of individuals.

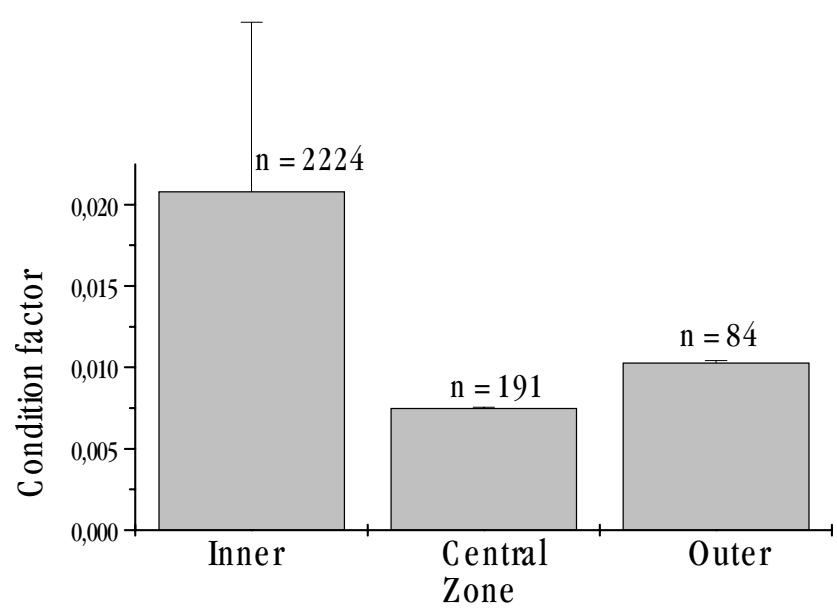

Figura 6. Means + standard error of condition factor for Micropogonias furnieri per size class in the Sepetiba Bay, Rio de Janeiro, from October 1998 to September 1999. $\mathrm{n}=$ number of individuals.

\section{DISCUSSION}

Micropogonias furnieri in the Sepetiba Bay presented inverse relationship between coefficient regression and constant of regression; in this study, differences in alometric coefficient were recorded between consecutive months, with some cases presenting positive alometric coefficient and others negative alometric coefficient. This suggested differences in structure size of population which were sampled each month; there was a trend for smaller individuals show lower alometric coefficient, while bigger individuals show higher alometric coefficient. On monthly basis it depart from three, except for November and April when they showed values closed to three. This overall value (2.99), on the other hand is in agreement with several authors and did not departure from three (GULLAND 1985, Weatherley \& Gill 1987, King 1995).
The parameter $\mathbf{b}$ represents growth alometric rate, and depends on genetically determined effects. If it stay constant and tending to assume values close to 3.0, it means that the individual did not change form along the ontogenetic growth. The regression coefficient and the constant regression present a remarkable inverse relation. BRAGA (1993) found an inverse variation between the regression coefficient and constant of regression for Paralonchurus brasiliensis due to seasonal variation in the physiologic state of the fish, expressed by the condition factor. ATKINSON (1989) analyzed the length-weight relationship for Coryphaenoides rupestris for different fishing areas in the Atlantic and found different values for the regression coefficients and constant of regression. This relationship can be explained by differences in environments and ontogeny of fish. Youngs-of-the-year tend to allocate a large amount of energy in growth, while adults put a considerable part of their energy in reproduction process or increasing weight. Smaller sized individuals present high growth rate and it was observed on the monthly variation in the regression coefficient which were correlated to constant regression, that is inversely related to condition factor BRAGA (1986). As the variation in the regression constant corresponds to the condition factor, that is, subject to seasonal oscillations, its variation can interfere in the variation of the regression coefficient. BRAGA (1997) suggests that the regression coefficient is not a good support indicator for characterization of different populations, because it can vary seasonally in the same population.

The condition factor presented higher values in the inner zone, due probably the largest input of organic matter from continental drainage, favoring organic enrichment of the local substratum (muddy), where predominate youngs-of-theyear and juvenile. In the outer zone, where larger sized fishes predominated, relatively high values were also detected. Differences in the condition factor have been interpreted as a measure of several biological events, such as fat reservations, adaptation to the environment and gonadal development (LE CREN 1951).

Higher condition factor were shown for LT $<50 \mathrm{~mm}$ individuals, mostly captured in the inner zone, and for adults 
presenting LT $=250-300 \mathrm{~mm}$, which were mostly captured in the outer zone. Mean values for condition factor varied among zones and size, indicating that youngs-of-the-year and adults can present higher condition independent of the time and distribution area.

ISAAC-NAHUM \& VAZZOLER (1983) studying the condition factor as indicator of the period of spawning in the north coast of São Paulo State, an adjacent area to Sepetiba Bay, found changing values over all year, presenting three peaks (May, August-October and December). The lowest values occurred in June, November and February, coinciding with higher frequency of emptied ovaries. In the present study also have been found three peaks (October-November, April and August) with the lowest values recorded from January to March, July and September. This suggest that the smallest individuals recorded in this study showed similar condition pattern to the population from São Paulo coast, confirming that they are from the same population I, as stated by VAzzoler (1991) for the Brazilian Southeast coast, where Sepetiba and São Paulo areas are included. Other important point to be raised is that $M$. furnieri presented a resting period in the summer in the coast of São Paulo, while in the Sepetiba Bay the lowest values were recorded for the condition factor in these months, that takes to suppose that a rest prolonged period during the summer also exists, although we don't have clear evidences of such facts, since we didn't analyze reproductive aspects of this species.

Youngs-of-the-year (LT $<50 \mathrm{~mm}$ ), which occur basically in the inner zone, presented higher condition factor values. Falkland currents penetrate through west Bay side, probably transport can bring into the bay eggs and larvae from $M$. furnieri spawning; after eclosion, recruits would benefit of the high productivity in this zone, where they are found in high abundances, and show fast development, that justifies the high values of the condition factor in this zone.

Juveniles and adults also presented high condition factor values in the outer zone, and this can be associated to the fact of these fish reach sexual maturity and allocate energy to reproductive process. According to VAzzoler (1991) M furnieri from southeast Brazilian coast (population I) reach the first maturation at $250 \mathrm{~mm}$ LT for males and $275 \mathrm{~mm}$ LT for females.

Isometric growth for M. furnieri in Sepetiba Bay and best conditions in the first phases of the life cycle, when larger part of the energy is allocated for growth, thanks to high organic matter due to the contribution of continental drainage in the inner zone, can be associated to more unstable and stressing conditions, which doesn't seem to be a limitant factor for the development and rearing of this species in the Bay. This species seems to have developed adaptative processes for using this Bay area and supporting adverse conditions.

\section{CONCLUSIONS}

Micropogonias furnieri shows isometric growth in the Sepetiba Bay, not changing shape along ontogenetic phases. The alometric coefficient change inversely with constant regression, shifting values among the months and indicating changes in population structure. The best fish condition was recorded during the winter and spring. The best fish condition in the innermost area of the Bay coincided with dominance of the smallest sized individuals.

\section{ACKNOWLEDGEMENTS}

The authors thank to FAPERJ (Fundação Carlos Chagas de Amparo á Pesquisa do Estado do Rio de Janeiro) for financial assistance. We also thank all colleague of Laboratory of Fish Ecology for help in field work.

\section{REFERENCES}

Anderson, O.R. \& R.M. Neumann. 1996. Length, weight and associated structural indices, p. 447-482 In: L.A. NiELSEN \& D.L. Johnson (Eds). Fisheries Techniques. Bethesda, American Fisheries Society, 732p.

Araújo, F.G.; A.G. Cruz-Filho; M.C.C. Azevedo \& A.C.A. Santos. 1998. Estrutura da comunidade de peixes demersais da Baía de Sepetiba. Revista Brasileira de Biologia, Rio de Janeiro, 58 (3): 417-430.

Araújo, F.G.; A.G. Cruz-Filho; M.C.C. Azevedo; A.C.A. Santos \& L.A.M. FERnANDES. 1997. Estrutura da comunidade de peixes jovens da margem continental da Baía de Sepetiba, RJ. Acta Biologica Leopoldensia, São Leopoldo, 19 (1): 61-83.

AтKinson, D.B. 1989. Weight-length relationship of roundnose grenadier (Coryphaenoides rupestris) (Gunnerus, 1765) in different areas of the North Atlantic. Fisheries Research, Amsterdam, 7: 65-72.

Beyer, J.E. 1987. On lenght-weigth relationships. Part I: Computing the mean weight of the fish of a given lenght class. Fishbyte, Manila, 5: 11-13.

Bolger, T. \& P.L. Connolly. 1989. Selection of suitable indices for the measurement and analysis of fish condition. Journal of Fish Biology, Dumfries, 34: 171-182.

BRAGA, F.M. DE S. 1986. Estudo entre fator de condição e relação peso-comprimento para alguns peixes marinhos. Revista Brasileira de Biologia, Rio de Janeiro, 46 (2): 339-346.

. 1993. Análise do fator de condição de Paralonchurus brasiliensis (Perciformes, Sciaenidae). Revista UNIMAR, Maringá, 15 (2): 99-115.

— 1997. Analise da equação alométrica na relação pesocomprimento e o fator de condição em Plagioscion squamosissimus (Teleostei, Sciaenidae). Revista Brasileira de Biologia, Rio de Janeiro, 57 (3): 417-425.

Coelho, V.M.B. \& R.R. Carvalho. 1973. Levantamento sanitário da Baía de Sepetiba e suas possibilidades como corpo receptor de cargas poluidoras da região. Rio de Janeiro, Publicações avulsas FEEMA, 87p.

GulLAND, J.A. 1985. Fish stock assessment: a manual of basic methods. Chichester, John Wiley \& Sons, 223p.

Issac-Nahum, V.J. \& A.E.A. DE M. Vazzoler. 1983. Biologia reprodutiva de Micropogonias furnieri (desmarest, 1823) (Teleostei, Sciaenidae). 1. Fator de condição como indicador do período de desova. Boletim do Instituto Oceanografico, São Paulo, 32 (1): 63-69.

KING, M. 1995. Fisheries biology, assessment and management. Oxford, Fishing News Books, 341p.

LE CREN, E.D. 1951. The lenght-weight relationship and seasonal cycle in gonad weight and conditions in the perch Perca fluviatilis. Journal of Animal Ecology, London, 20 (2): 201219.

Menezes, N.A. \& J.L. Figueiredo. 1980. Manual dos peixes marinhos do sudeste do Brasil. IV. Teleostei (3). Museu de Zoologia, Universidade de São Paulo, São Paulo, 96p. 
VAzzolER, A.E.A. DE M. 1991. Síntese de conhecimentos sobre a biologia da corvina Micropogonias furnieri (Desmarest,1823), na costa do Brasil. Revista Atlântica, Rio Grande, 13 (1): 55-74.

. 1996. Biologia da reprodução de peixes teleósteos: teoria e prática. Maringá, EDUEM, 169p.

VAzzoler, A.E.A. DE M. \& V.N. Phan. 1981. Ocorrência de catara- ta em Micropogonias furnieri (Desmarest, 1823), na área entre Cabo Frio e Torres $\left(23^{\circ} \mathrm{s} 29^{\circ} \mathrm{s}\right)$, Brasil: Investigação de causas e estudo eletroforético das proteínas totais dos cristalinos. Boletim do Instituto Oceanográfico, São Paulo, 30 (1): 65-76.

Weatherley, A.H. \& H.S. Gill. 1987. The biology of fish growth. London, Academic Press, 443p.

Received in 06.V.2003; accepted in 11.XI.2003.

Revista Brasileira de Zoologia 20 (4): 685-690, dezembro 2003 